\title{
Optimization of Legal Protection for Consumers in the On Line Sale and Purchase Agreement
}

\section{Dharu Triasih, B Rini Heryanti, and Endah Pujiastuti}

\section{Abstract}

Globalization is characterized by the development of communication technology makes people more easily connect with others. One of the significant developments now is the sale and purchase transactions online or E-Commerce.Penjual and buyers do not need to face to face (transaction to face) to make transactions and buy, but only need to have an internet connection that will bring them in the virtual world. a legal review is conducted to prevent the occurrence of legal disputes between the parties. The approach method used in this research is empirical juridical approach. The study was conducted in the city of Semarang, which was determined pourposively. Data collection by literature study and interview. Qualitative analysis with deduction and induction methods. The results showed that the main principle of online transactions in Semarang prioritize the trust aspects between the parties. Principles of online transaction security security such as guarantee on the identity of seller / buyer, payment gateway security, security guarantee and reliability of electronic commerce website have not become main concern for sellers and buyers, especially on small to medium scale transaction with value nominal transaction that is not too large. The conclusion is that the legal protection for the consumer has not been reached optimally in the sale and purchase agreement on line.

Keywords: Consumer Protection, agreement, buying and selling

\section{Introduction}

the responsibility of the First ELEHIC Conference Committee.

\subsection{Background}

Globalization is characterized by the development of communication technology makes people more easily connect with others. One significant development now is online buying and selling transactions or E-Commerce. Sellers and buyers do not need to face to face (transaction to face) to make buying and selling transactions, but only need to 
do legal studies related to it to prevent the occurrence of legal disputes between the parties.Perkembangan technology information and telecommunications cause the world to be borderless and cause significant social change to take place so quickly. However, even though it was originally created to generate positive benefits, it is possible to be used for negatives. The activities of commerce by utilizing this internet medium are known by the term electronic commerce, or abbreviated to commerce. [1]

E-Commerce is a process of buying and selling goods and services made through a computer network, the internet.Jualbeli online can streamline and mengefisiensikan time so that a person can make a sale and purchase transactions with every person wherever and whenever. All transactions via internet and internet is done without any face to face between the parties, they base the sale and purchase transactions on the trust of each other, so that the purchase agreement that occurs between the parties was done electronically.

Through all the formalities commonly used in conventional transactions are reduced, besides of course consumers have the ability to collect and compare information such as goods and services more freely without being limited by borderless. E-commerce not only provides convenience for consumers, but this development makes it easier for manufacturers to market products that have an impact on cost and time savings.

Trading transactions via the Internet is different from shopping or trading transactions in the real world. Through e-commerce, where the buyer (buyer) access the internet to the website, which then the buyer (buyer) looking for the desired goods.Apabila have found the desired goods, buyer send offer in the seller's page, call, or send a short message to seller. After a bargain and an agreement then seller and buyer will determine the payment mechanism. Payment mechanism commonly used is the buyer to transfer some money to seller. After buyer to transfer money then seller send goods to buyer. But the payment with the transfer mechanism has a high risk because of the possibility of fraud large enough. Beru demanded to be very careful if you want to do transactions with the transfer mechanism. Mechanisms include cash on delivery (COD), kaspay, and joint accounts (rekber). Cash on delivery is a system of buying and selling by meeting face to face, checking the condition of the goods and completeness, negotiation, then making payments.

Implementation of online buying and selling agreements in practice raises several problems, such as buyers who get goods that are not in accordance with the ordered, late delivery of goods, damage to the goods received. 


\subsection{Problem}

Based on the above background, the formulation of the problem to be discussed is how is legal protection for consumers in buying and selling agreements on line?

\section{Methods}

Method The approach used in this study is the method of empirical juridical approach is a study that emphasizes the science of law, but in addition it also seeks to examine the rules of law applicable in society.

This research is conducted by collecting and studying primary, secondary, and tertiary legal materials. According Soerjono Soekanto argues that: "A legal research is basically a scientific activity based on methods, systematics and certain thoughts that aims to study one or some specific legal phenomena by analyzing it, except that there is also held a deep examination of the legal facts for then what is caused in the symptoms concerned ". [2]

Primary legal materials include: KUHPerdata book III on Alliance, Law Number: 8 Year 1999 on Consumer Protection, Law Number: 11 Year 2008 on Information and Electronic Transactions. Secondary legal data material, is a legal material that provides guidance and explanation of the primary legal material such as material other documents related to the problems studied tertiary legal material, supporting legal materials that provide guidance and explanation of secondary law material and primary law dictionary - laws, magazines / journals or newspapers insofar as they pertain to information relevant to the research material. The field research study was conducted to obtain primary data, with the technique of conducting in-depth interviews with informants and respondents that the researchers had determined.

\section{Results and Discussion}

\subsection{Legal protection for consumers under on sale purchase agree- ment}

\subsubsection{Legal relation between consumer and business actor}

Legal relationships that occur in conventional trading and selling involves only between two parties, namely the seller and the buyer. The legal relationship is in the form of an agreement that results in legal consequences, namely the rights and obligations of the 
seller and also the rights and obligations of the buyer. which is abbreviated as UUPK. Likewise with the rights and obligations of sellers or business actors are also protected by UUPK. In the Consumer Protection Act regulated on consumer rights, Article 5 of Law Number 8 of 1999 concerning Consumer Protection states that consumer rights are: [3]

1. Right to comfort, safety and safety in consuming goods and / or services;

2. The right to choose goods and / or services and obtain the goods and / or services in accordance with the exchange rate and the conditions and guarantees promised;

3. The right to true, clear and honest information about the condition and guarantee of goods and / or services;

4. The right to be heard of his opinions and complaints on goods and / or services used;

5. The right to appropriate advocacy, protection, and dispute resolution efforts for consumer protection;

6. Right to education and consumer education;

7. The right to be treated or served properly and honestly and not discriminatively;

8. The right to get compensation, compensation and / or replacement, if the goods and / or services received are not in accordance with the agreement or not as they should be.

On the other hand, the obligations for business actors (in this case are online sellers), pursuant to Article 7 of Law Number 8 Year 1999 concerning Consumer Protection are: [4]

1. Good faith in doing business;

2. Provide true, clear and honest information about the condition and guarantee of goods and / or services and provide explanations of use, repair and maintenance;

3. Treat or serve consumers correctly and honestly and not discriminatory;

4. Ensure the quality of goods and / or services produced and / or traded under the provisions of the applicable quality standards of goods and / or services;

5. Provide an opportunity for consumers to test, and / or try certain goods and / or services and provide warranty and / or guarantee on manufactured and / or traded goods; 
6. Compensate, indemnify and / or reimburse for losses arising from the use, use and utilization of traded goods and / or services;

7. Give compensation, compensation and / or reimbursement if the goods and / or services are received.

In buying and selling transactions via the internet, related parties include:

1. The seller or entrepreneur who offers a product through the internet as a business actor;

2. Buyer or consumer, ie any person who is not prohibited by law, who receives offers from sellers or business actors and wishes to conduct sale and purchase transactions offered by sellers / business actors;

3. Bank as the channel of funds from buyer or consumer to the seller, because in the transaction of buying and selling electronically, the seller and the buyer do not deal directly, because they are in different location so that payment can be done through intermediary, in this case is bank;

4. Provider as internet access service provider.

Implementation of the sale and purchase transactions through the internet is done without any face to face between the parties, so that the sale and purchase agreement that occurs between the parties was also done electronically either through e-mail or other means. The sale and purchase transactions conducted through the internet can not be stopped, even every day is always found the latest technology in the world of internet, while the protection and legal certainty for the internet users is not sufficient, thus must be strived to keep the legal balance in those conditions.

LP2K Chairman of Semarang, Ngargono revealed, when viewed from the complaints report, online consumers are quite a few. Recorded, there are only 4 reports received However, the potential loss of consumers online is much greater than conventional consumers.

"The online transaction is like an iceberg phenomenon. It could be, the reports are few but the facts on the ground are very much harmed," Ngargono said, to the Central Java Tribune. This is inversely proportional to the bidding of buy and sell transactions in place which reached 30 reports last year.

In fact, there is a meeting between the seller and consumers and consumers directly see or check the product to be purchased. [5] 


\subsubsection{Consumer and product sues}

The general weakness of consumers in general is never to read the information about the terms and conditions applied by the site owner. The terms and conditions contained in the site are the main rules that must be observed jointly by both the seller, the buyer and the owner of the site. It can be found that in the content of the terms and conditions contained by certain sites only regulate the security of the site owner and ignore the interests of its customers. Although this unilateral arrangement violates the law, in particular the provisions of Article 18 of Law No. 8 of 1999 on Consumer Protection, but due to the lack of legal enforcement efforts, such circumstances continue. Often what happens is the owner of the site irrespective of the portion of which is the responsibility, whereas the site owner benefits economically if more people access and use the site to transact.

As a lawsuit, it is the right of the consumer itself to indemnify the business actor. However, because the nature of the lawsuit is "right" so there is no compulsion for the consumer to file the lawsuit. This is very unfortunate. Although the nature is only in the form of rights, but with that right, the rights of consumers to get protection that has been guaranteed by the UUPK can be realized. Many reasons why the disadvantaged consumers do not file a claim against the responsibility of the product. Among them is because the community has a tendency to feel ashamed to fight it and also pay attention to the limitations of knowledge about their rights which are basically protected by law when they file a claim for compensation to the business actor to court.

Consumers who did not file the lawsuit were also influenced by their lack of understanding of the mechanisms to be faced in the context of court proceedings. This is related to the lack of knowledge and education of consumers who also affect the level of legal awareness. Therefore, it is very necessary role of some non-governmental organizations to be able to conduct counseling against those who are disadvantaged due to the behavior of business actors. Furthermore, because they have not obtained an adequate proof. To get a proof and stretch it in court is not easy. Because in addition to the victim or the consumer must be able to prove the existence of a causality relationship between the conduct of the business actor and the loss of the consumer, the business actor can also submit a counter argument that can counter the evidence presented by the consumer.

Economic factors are one factor that causes the position of business actors to be stronger than consumers. Against consumers who have medium economic condition down will feel a fear when dealing with the business actor. Not excessive indeed, 
because the majority of business operators themselves are from the upper middle class economy. It can be ascertained, consumers will experience an intervention not only those that are material but also immaterial. In addition to economic factors, educational factors and low consumer knowledge also became one of the causes of an imbalance between the position of consumers and business actors. While it can not be denied that many of the consumers are someone who has a pretty good academic background but that does not apply in the context of the business world. Sometimes business actors dominate it more.

Article 8 of Law Number 8 Year 1999 concerning Consumer Protection prohibits business actors to trade goods / services that are inconsistent with the promises stated in the label, etiquette, description, advertisement or promotion of the sale of such goods and / or services. Based on this article, the non-conformity of the goods specifications received with the goods listed in the advertisement / photo of the goods offer is a form of violation / prohibition for business actors in trading goods. Consumers pursuant to Article 4 Sub-Article H of Law Number 8 Year 1999 regarding Consumer Protection are entitled to compensation, compensation and / or reimbursement if the goods and / or services received are not in accordance with the agreement or not as they should be. Whereas, the business actor itself pursuant to Article 7 Sub-Article $g$ of the UUPK shall be obliged to provide compensation, compensation and / or reimbursement if the goods and / or services received or utilized are not in accordance with the agreement. If a business actor does not carry out his obligations, the business actor can be convicted under Article 62 of Law Number 8 of 1999 concerning Consumer Protection, which reads:

Business actors violating the provisions referred to in Article 8, Article 9, Article 10, Article 13 paragraph (2), Article 15, Article 17 paragraph (1) letter a, letter b, letter c, letter e, paragraph (2) and Article 18 shall be punished with a maximum imprisonment of 5 (five) years or a fine of a maximum of Rp. 2,000,000,000.00 (two billion rupiahs).

\subsection{Consumer protection under the ITE law}

The birth of UUITE is a dilemma, and there are still many shortcomings in providing legal certainty of buying and selling over the internet, because technological and industrial advances are increasingly rapid, inevitably impact our country, especially electronic transactions, with e-banking, e-commerce, and other electronic transactions.

With the increasing number of electronic transactions carried out, it also encourages the need for legal provisions governing the matter, so that the parties involved in electronic transactions, especially consumers, get legal protection for every electronic 
transaction they do. Likewise, data / documents that are made electronically (paperlessdocument) also require certain legal force, considering that all this time, documents / deeds are only considered valid when written on paper (paperless). In overcoming the above problems, then the legal provisions contained in the Civil Code can still be applied to buying and selling transactions electronically, among others, Article 1457 of the Civil Code stated that "Buying and selling is an agreement that one party binds itself to submit a material and one party others to pay the promised price.

Buying and selling transactions, even if done online, based on the ITE Law and PP PSTE remain recognized as electronic transactions that can be accounted for. Approval to buy goods online by clicking the agreement on the transaction is a form of acceptance that states agreement in an agreement on an electronic transaction. Such acceptance actions are usually preceded by a statement of approval of the terms and conditions of sale and purchase online as one form of Electronic Contract. Electronic Contracts according to Article 47 paragraph (2) PP PSTE is considered valid if: [8 ]

1. There is agreement between the parties;

2. Performed by a competent legal subject or authorized to represent in accordance with the provisions of the legislation;

3. There are certain things; and

4. The object of the transaction must not be in conflict with the laws and regulations, morality and public order.

In addition there are several additional requirements in Article 48 of Government Regulation Number 82 of 2012 concerning Implementation of Electronic Systems and Transactions as follows:

1. Electronic Contracts and other contractual forms as referred to in Article 47 paragraph (1) addressed to the Indonesian population shall be made in Bahasa Indonesia.

2. Electronic Contracts made with standard clauses shall be in accordance with the provisions concerning the standard clause as stipulated in the laws and regulations

Electronic contracts at least include:

1. identity data of the parties;

2. objects and specifications;

3. Electronic Transaction requirements; 
4. prices and costs;

5. procedures in the event that there are cancellations by the parties;

6. provisions that give the aggrieved party the right to return goods and / or request a product replacement if there are hidden defects; and

7. Choice of electronic transaction settlement law.

The on-line purchase agreement itself can unknowingly become a joy for buyers who once feel well served or satisfied in transacting, thus then performing other similar transactions on the same site. Not infrequently among buyers have a sense of curiosity to access other on-line shopping sites. Trust or mutual trust is actually the main key of an on-line transaction. It is these beliefs that set aside traditional patterns of transacting by face to face. One will not know that the trust is injured until one day the person has a personal problem from an online transaction.

The main principle of online transactions in Semarang prioritizes aspects of trust between the parties. Principles of online transaction security security such as guarantee on the identity of seller / buyer, payment gateway security, security guarantee and reliability of electronic commerce website have not become main concern for sellers and buyers, especially on small to medium scale transaction with value nominal transaction that is not too large.

So with the existence of a legal umbrella that can protect the parties, whether the business actors or sellers or buyers or consumers will make it convenient to transact online and on the other hand, it will increase the turnover of business people by selling online. law of the market where the goods sold do not disappoint the buyer / according to the order and fast in the delivery of goods means that the service is always prioritized, then the consumer will not leave, ultimately the business turnover will increase and the company will always be known by the public or consumers. do not hesitate to do online buying and selling because online trading is a change of future transactions that originally conventionally shifted to online transactions.

\section{Conclusion}

The conclusion is that the legal protection for the consumer has not been reached optimally in the sale and purchase agreement on line. The main principle of online transactions in Indonesia still prioritizes aspects of trust or "trust" in sellers and buyers. The principle of online transaction infrastructure security, such as guaranteeing the correctness of the seller / buyer identity, guarantee of payment gateway security, security 
assurance and electronic commerce web site reliability is not yet a major concern for sellers and buyers, especially in small to medium scale transactions with value. nominal transaction that is not too large.

\section{References}

[1] Yuhadian, Muhammad Billah, Perjanjian Jual Beli Secara Online Melalui Rekening Bersama Pada Forum Jual Beli Kaskus, 2012,skripsi, Fakultas Hukum Bagian Hukum Keperdataan Universitas Hasanuddin., Makassar.

[2] Perdana,Afrian, Penyelesaian wanprestasi dalam perjanjian jual beli melalui media elektronik Jurnal IImu Hukum Pascasarjana Syiah Kuala/volume 2, no:1 Februari 2014

[3] Miru,Ahmadi\& Yodo,Sutarman, 2011,Hukum Perlindungan Konsumen, Jakarta, Raja Grafindo Perkasa

[4] Zulham,2013, Hukum Perlindungan Konsumen,Jakarta, Kencana Prenada Media

[5] Akhmaddhian,Suwari, Perlindungan Hukum Terhadap Konsumen Dalam Transaksi Jual Beli Secara Elektronik Di Indonesia, Jurnal Unifikasi, ISSN 2354-5976.vol.3 No.2 Juli 2016

[6] Tribunjateng.Com, Semarang, Kamis, 26 Januari 2017

[7] KUH Perdata

[8] http://www.hukumonline.com/klinik/detail//t50bf69280b1ee/perlindungankonsumen-dala-e-commerce/diakses 06 Juli 2018

\section{Author}

1. Name: Dharu Triasih, S.H, M.H

PT: Universitas Semarang

email: dharutriasih.fhusm@yahoo.co.id

2. Name: B. Rini Heryanti, S.H, M.H

PT: Universitas Semarang

email: riniheryanti@gmail.com

3. Name: Endah Pujiastuti, S.H, M.H

PT: Universitas Semarang

email: endahpujiastuti@usm.ac.id 